\title{
ВОЗМОЖНОСТИ РЕКОНСТРУКЦИИ ФРАГМЕНТИРОВАННЫХ КОСТЕЙ ЧЕРЕПА
}

\author{
Стоян А.O. \\ РГКП «Центр судебных экспертиз Министерства юстиции \\ Республики Казахстан», \\ Алматы, Республика Казахстан
}

В данной статье рассматривается вопрос реконструкции фррагментированных костей черепа. В качестве исследовательской задачи определена возможность использования термопластичного клея при реконструкции костной ткани. Обобщается практический опыт по исследованию костных останков скелетированных трупов, обнаруженных в период 20162021 годы на территории Южного Казахстана. Выделяются и описываются характерные особенности разработанного метода по неинвазивному изучению скелетированного материала плохой сохранности.

Ключевые слова: фррагментация, деструкция кости, кости черепа, реконструкция костной ткани.

Высокая давность захоронения костных останков нередко служит причиной их фррагментации [1]. Хрупкая костная ткань может также быть разрушена в ходе ее извлечения из грунта и транспортировки органами полиции [2]. Между тем, в ходе идентификации личности, при определении половой и расовой принадлежности, важная роль отводится вопросам реконструкции фррагментированных костей черепа [3].

В этой связи в медико-криминалистических отделениях судебной экспертизы Республики Казахстан часто возникает необходимость исследования фррагментированных костей черепа. Их реконструкция позволяет установить не только половую и расовую принадлежность, но и прижизненные возраст и рост. В странах ЕС и США постмортальная реконструкция проводится с помощью компьютерных 3D-моделей и 3D-печати [4]. Для этой цели в костях черепа с помощью сверла делаются отверстия, в которые вставляются металлические скобы [5]. Данный метод требует больших затрат времени и является трудоемким, а также может приводить к порче костного препарата. Другим использумым методом является склеивание фррагментов кости цианакрилатным клеем, а также клеем, используемым в стоматологической практике [6]. Оба эти материала являются дорогостоящими.

В рамках практических работы по идентификации личности в медико-криминалистическом отделении «Института судебных экспертиз по городу Алматы» были произведены исследования по реконструкции костной ткани с использованием термопластичного клея [7]. Важно подчеркнуть, что в отечественной судебно-медицинской литературе, а также судебно-медицинской литературе ведущих стран мира отсутствует информация по заявленному выше методическому подходу. Термопластичный клей обладает множеством достоинств - он не только может склеивать различные поверхности, но и способен заполнять пустоты, обладает малой усадкой и

Адрес для корреспонденции: Стоян Анастасия Олеговна, судебно-медицинский эксперт, Институт судебных экспертиз по городу Алматы РГКП «Центр судебных экспертиз Министерства юстиции Республики Казахстан», Тел.: +7(705)105-83-93, эл. почта: lira_88@mail.ru 
высокой скоростью полимеризации. Также примечательно то, что данный клей не требует предварительной обработки костной ткани химическими реактивами и отличается низкой стоимостью. Очевидно, что внедрение в постмортальную практику реконструкции костной ткани разработанного метода позволит судебно-медицинским экспертам сократить время проведения исследований костных останков.

Приведенный ниже перечень процедур был вызван тем обстоятельством, что на исследование в «Институт судебных экспертиз по городу Алматы» Республиканского государственного казенного предприятия «Центр судебных экспертиз Министерства юстиции Республики Казахстан» 03 июня 2020 года из следственного отдела управления полиции Талгарского района поступило постановление от 14 мая 2020 года о назначении судебно-медицинской (медико-криминалистической) экспертизы по факту обнаружения костных останков, которые были найдены в ходе проведения строительных работ в поселке Бескайнар Талгарского района. В первую очередь следует отметить, что при проведении реконструкции костной ткани с использованием термопластичного клея в условиях медико-криминалистического отделения «Института судебных экспертиз по городу Алматы» были выполнены следующие процедуры:

- проведено краткое описание случая и вынесено постановление о необходимости проведения судебно-медицинской экспертизы костных останков;

- разработан алгоритм экспертных исследований по проведению идентификации личности.

Следует уточнить, что среди костных останков просматривалось 17 фррагментов черепа. Кости черепа были сопоставимы между собой. Для реконструкции черепа было принято решене воспользоваться вышеупомянутым термопластичным клеем, который приобретает требуемые адгезионные характеристики при нагревании в клеевом пистолете. Благодаря композиционному составу клея содержащему этиленвинилацетат и полиамид последний становится жидким при нагревании и после применения имеет способность быстрого застывания.

В ходе выполненных исследований, с применением положений изложенных в разработанной методике удалось провести реконструкцию черепа по 12 его фррагментам. При этом сопоставить остальные 5 фрагментов не удалось по причине выкрашивания их краев.

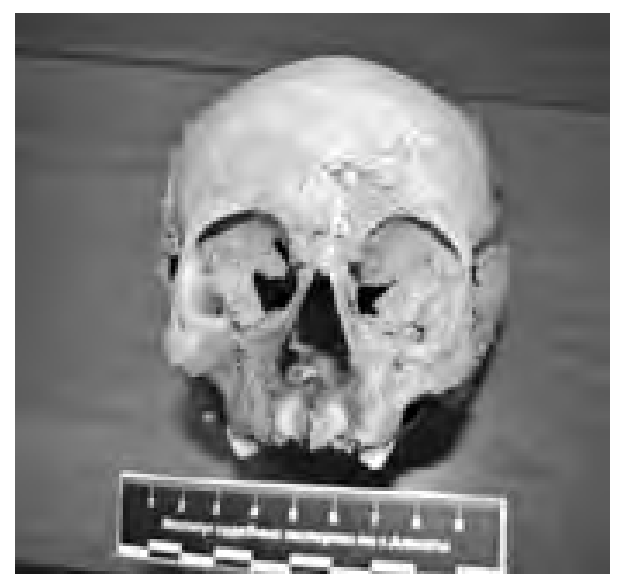

Рис. 1 Череп, вид спереди.

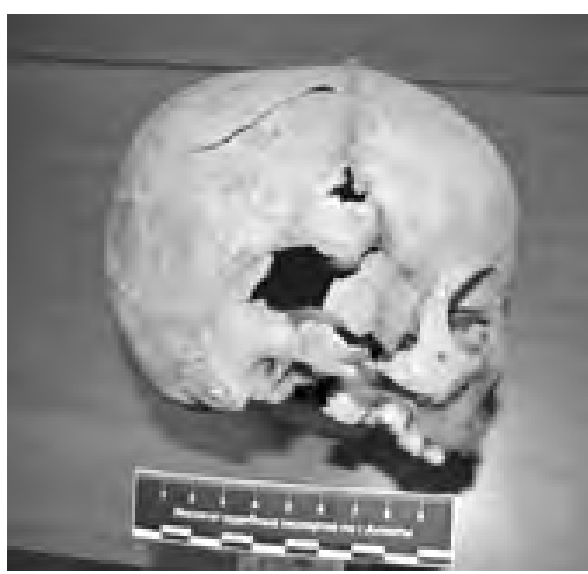

Рис. 2 Череп, вид справа. 


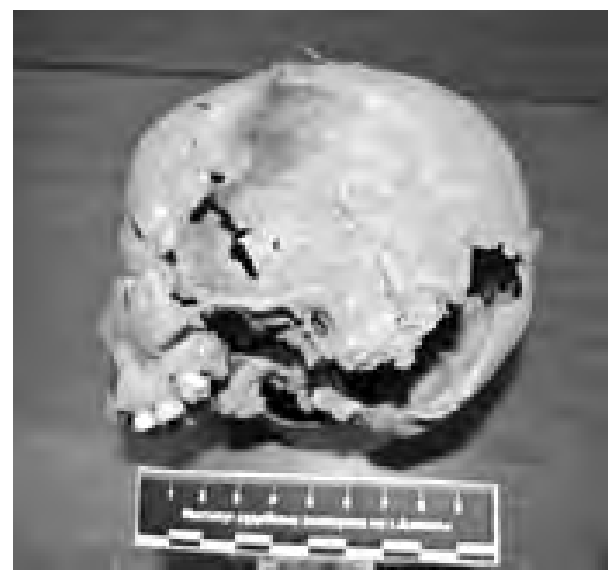

Рис. 3 Череп, вид слева.

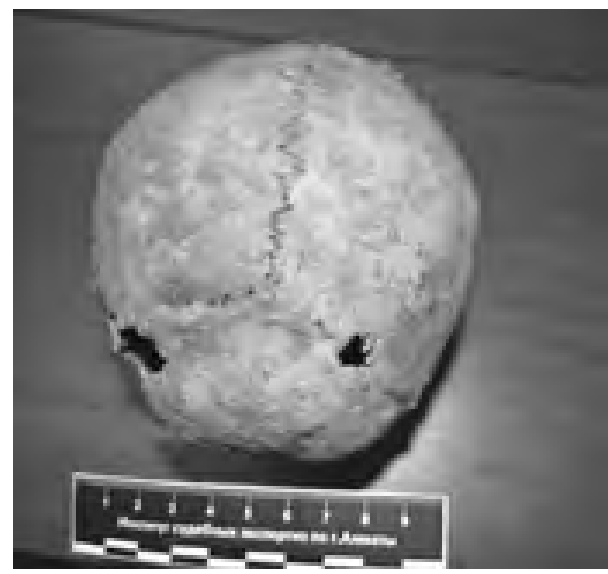

Pис. 5 Череп, вид сзади.

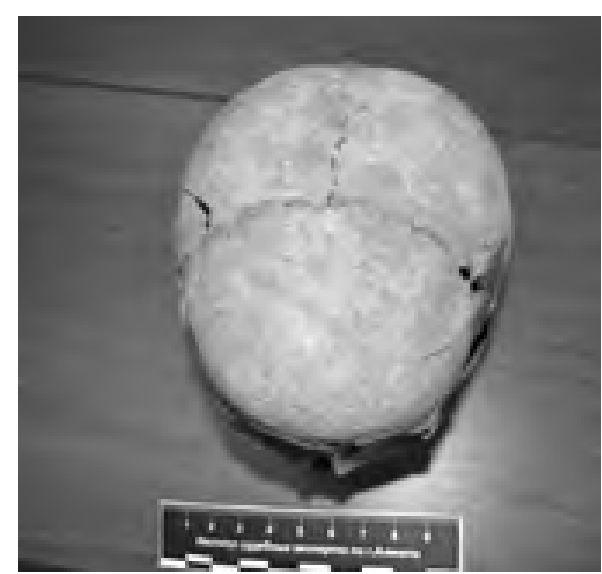

Pис. 4 Череп, вид сверху.

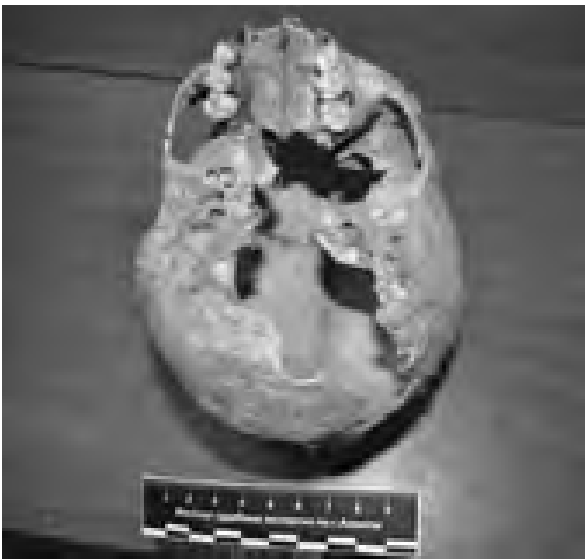

Рис. 6 Череп, вид изнутри.

После реконструкции удалось установить видовую, половую и расовую принадлежность черепа индивидуума, который принадлежал ребенку биологического возраста 3-5 лет, представителю монголоидной расы с наличием отдельных европеоидных признаков.

Таким образом, при постмортальной реконструкции фррагментированных костей черепа рекомендуется придерживаться следующей последовательности выполняемых шагов:

1. Произвести очищение костных останков от наложений грунта.

2. Предпринять попытку сопоставления костных фррагментов до их склеивания по швам или линиям отделения. Вместе с тем, при восстановлении первоначальной формы черепа желательно сначала сопоставить между собой крупные фрагменты черепа, чтобы избежать искажения его первоначальной формы.

3. В случае возможности сопоставления, с помощью клеевого пистолета, нанести клеящий состав на склеиваемые поверхности. Важно иметь ввиду, что при постмортальной реконструкции, в соответстии с разработанной методикой, необходима высокая скорость работы по причине быстрого застывания клея.

Следует отметить, что методика имеет ограничения, так как для случаев выкрашивания соединяемых поверхностей, сопоставление не всегда возможно. Однако разработанная методика все же позволяет проводить идентификацию личности даже при исследовании фррагментированных черепов. 


\section{Список литературы}

1. Пашкова В.И. Очерки судебно-медицинской остеологии. - Москва, «Медгиз», 1963.

2. Герасимов М.М. Восстановление лица по черепу. - М., 1955.

3. Пашкова В.И., Резников Б.Д. Судебно-медицинское отождествление личности по костным останкам. - Саратов, 1978.

4. Белов Н.Н., Югов Н.Т., Ищенко А.Н., Афанасьева С.А., Хабибуллин М.В., Югов А.А., Стуканов А.Л. Математическое моделирование разрушения костной ткани при динамическом нагружении. Журнал «Вестник Томского государственного университета. Математика и механика, 2010.

5. Калмина О.А., Калмин О.В., Сингатулин Р.А. 3D-реконструкция анатомических структур в системах виртуальной реальности. Известия высших учебных заведений. Поволжский регион. Медицинские науки, 2010.

6. Forensic medical forum. - [Электронный ресурс] - www.forens.ru/ Дата обращения 05.08.2020.

7. Термопластичный клей- [Электронный ресурс] - www.ru.m.wikipedia/ Дата обращения 15.09.2020.

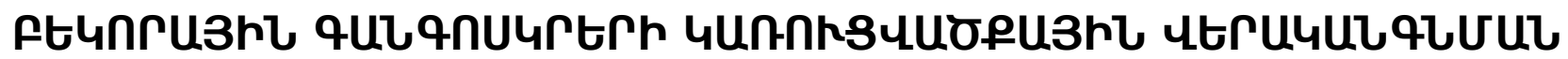

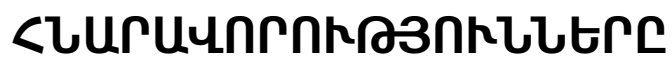

\section{Uупnנwध U.O.}

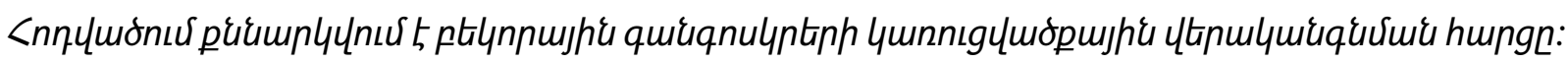

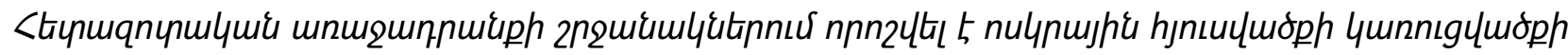

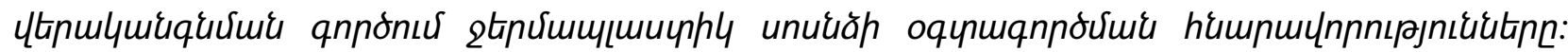

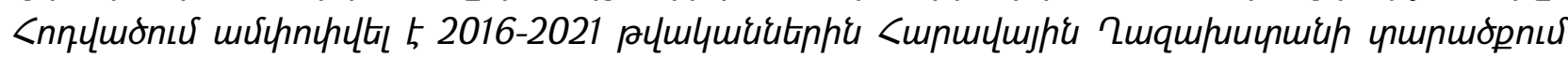

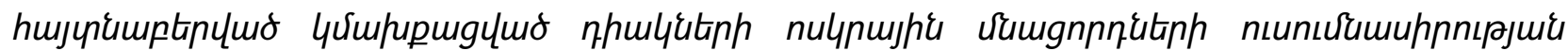

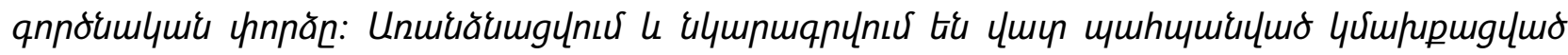

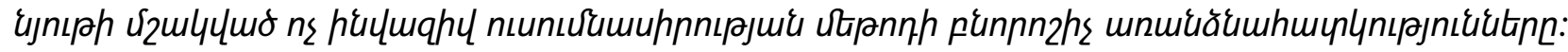

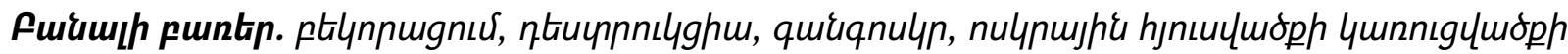
पthnulumiquens:

\section{RECONSTRUCTION POSIBILITIES OF DESTROYED BONES OF SCULL}

\section{Stoyan A.}

High age of the bone burial quite often is a reason of it fragmentation [1]. Fragile bone tissue may be destroyed in the path of extraction from the priming and transportation from police [2]. By the way, bone destruction exactly plays role in the cases of sex and race identification, absence of needed fragments and postmortal deformation [3]. In the article described the problem, and proposed the possibilities of skull bone reconstruction in the cases of fragmentation.

Key words: fragmentation, bone destruction, skull bones, bone reconstruction.

Статья поступила: 28.04.2021

Принята к печати:06.12.2021 